\section{Ekologie roślin i wiedzy}

Małgorzata Sugiera

TEKSTY DRUGIE 2018, NR 2, S. 41-56

DOI: $10.18318 /$ td.2018.2.3
Niniejszy tekst powstał w ramach projektu badawczego Narodowego Centrum Nauki "Performanse pamięci: strategie testymonialne, rekonstrukcyjne i kontrfaktyczne $w$ literaturze isztukach performatywnych $\mathrm{XX}$ i XXI wieku" (UMO-2014/15/G/ $\mathrm{HS}_{2} / 04803$ ).

\section{Wytwarzanie światów}

„Nie możemy stać się niewolnikami naszych założeń. [...] Nie stawiliśmy jeszcze czoła przerażającemu zgoła wyzwaniu Roślin"1" - przekonuje prezydent Therolinguistics Association w redakcyjnym wstępie do jednego z numerów czasopisma, którego dwa fragmenty przedrukowała Ursula Le Guin w opowiadaniu The Author of the Acacia Seeds. Jeśli pozbawiona z założenia komunikacyjnych intencji, wegetatywna sztuka roślin w ogóle istnieje - kontynuuje swoją argumentację - oznacza to, że od nowa przemyśleć należy same podstawy istniejącej

1 U.K. Le Guin The Author of the Acacia Seeds and Other Extracts from the "Journal of the Association of Therolinguistics" [1974], http://interconnected.org/home/more/2007/03/acacia-seeds.html (25.03.2018). Polska wersja: Rękopis na ziarenkach akacji i inne materiały z „Przeglądu Naukowego Towarzystwa Zoolingwistycznego", przeł. B. Kluczborska, w: U.K. Le Guin Dziewczyny Buffalo oraz inne zwierzęce obecności, Wydawnictwo Alkazar, Warszawa 1993. Ponieważ kluczowe dla mojej interpretacji sformułowania nie znalazły w przekładzie adekwatnego odzwierciedlenia, korzystam z wersji oryginalnej.

\section{Małgorzata Sugiera}

- prof. dr hab., kierownik Katedry Performatyki UJ. W latach 2015/2016 prowadziła badania W IRC "Interweaving Performance Cultures" na FU w Berlinie, a rok później na Universidade de São Paulo w Brazylii. Wydała 12 monografii autorskich, ostatnio Nieludzie. Donosy ze sztucznych natur (2015) oraz z Mateuszem Borowskim Sztuczne natury. Performanse technonauki i sztuki (2016). Zajmuje się także tłumaczeniem prac naukowych i sztuk teatralnych. 
wiedzy, wypracować nowe metodologie i narzędzia badań. Udana rekonstrukcja naukowych paradygmatów oznaczać zaś będzie w konsekwencji istotną zmianę w sposobie postrzegania świata. Już niedługo fitolingwiści nie tylko nauczą się czytać mowę bakłażanów i odcyfrują lirykę porostów, powstanie też kolejna gałąź wiedzy - geolingwistyka. Dotrze ona pod warstwę porostów, aż do pokładów atemporalnej i zimnej poezji skał, spisanej wybuchami wulkanów i trzęsieniami ziemi, ujętej w metrum tektonicznych uskoków. Świat stanie się wtedy jedną wielką Księgą, możliwą wreszcie do odczytania w całości przez wyspecjalizowanych lingwistów, których dziś moglibyśmy nawet nazwać ekspertami od języka Gai². Utopijna wizja przyszłości, którą rysuje tu Le Guin, zdaje się jednak o wiele bardziej krytyczna wobec nauki i możliwości przesuwania granic wiedzy, niż mogłoby się na pierwszy rzut oka wydawać.

W wymyślonym w połowie lat 70. XX wieku świecie The Author of the Acacia Seeds, naukowcy dobrze już poznali języki zwierząt. Choć grecki termin thēr thêrós, który pojawia się w nazwie ich zrzeszenia, odnosi się przede wszystkim do ssaków, dwa wcześniejsze przedruki analizują komunikaty mrówek i pingwinów. Znalezione w mrowisku tytułowe nasiona akacji, pozbawione żywych zarodków i ułożone w równe szeregi, zapisane zostały specjalną wydzieliną. Tekst da się wprawdzie odczytać, lecz jego sens musi pozostać dalece fragmentaryczny ze względu na specyfikę koniugacji. Większość dialektów mrówek zna jedynie trzecią osobę liczby pojedynczej i mnogiej oraz pierwszą osobę liczby mnogiej. Nie sposób zatem ustalić, czy w tym przypadku chodzi o rodzaj poetyckiej autobiografii czy raczej manifest. Podejmujący dyskusję na temat tego znaleziska lingwista zwraca również uwagę na przegapione wcześniej pułapki etnocentrycznej perspektywy: tylko dla żyjących na powierzchni ziemi ludzi wyrażenie "do góry" ma pozytywne konotacje; dla mrówek oznacza nieodwołalnie wygnanie i śmierć. Podobnych pułapek nie brakuje gdzie indziej, choćby w studiach nad komunikacją pingwinów, które posługują się językiem wielowymiarowej choreografii. Błędem okazały się jednak próby czytania ich przekazów przez pryzmat lepiej znanych, ruchowych scenariuszy delfinów. Nie brały one bowiem pod uwagę tego, że wbrew wszelkim pozorom pingwiny wcale nie pływają - one latają w wodzie i składają jaja,jak wszystkie inne ptaki. „Różnica całego świata sprowadza się

2 O Gai jako nowej postaci natury, która coraz bardziej ujawnia własną sprawczość, pisze choćby Isabelle Stengers, por. I. Stengers In Catastrophic Times. Resisting the Coming Barbarism [2009], przeł. A. Goffey, Open Humanities Press 2015. 
do tego zwykłego faktu"3 - podkreśla autor raportu o wyprawie badawczej w krainę pingwinów królewskich. Nie bez przyczyny kazała mu Le Guin posłużyć się w tym zdaniu idiomatycznym wyrażeniem „a world of difference", podobnie jak nie bez przyczyny umieściła wstęp od redakcji dopiero jako trzeci fragment opowiadania, otwierając je relacją o zapiskach anonimowej mrówki, zbliżonych do prototypowych dla nas tekstów pisanych. Ten zabieg, jak podejrzewam, powinien zachęcić czytelników The Author of the Acacia Seeds do krytycznej lektury umieszczonej w zakończeniu utopijnej wizji świata, który dzięki postępom lingwistyki uzyska jednorodność i zrozumiałość. Pozorną jednorodność i zrozumiałość, jak podkreśla Le Guin.

W przypadku utopijnej wizji lingwistyki jako królowej nauk zwrócenie uwagi na „różnicę całego świata", która dzieli odmienne praktyki życiowe, musi ujawnić złudę projektu wiedzy uniwersalnej. Wrażenie jednorodności pojawia się przecież w efekcie niemal magicznego zabiegu nazwania tym samym słowem ,język" wielorakich i wielorodnych praktyk, świadomego ukrycia pod jedną i tą samą nazwą odmiennych zabiegów metaforyzacji zjawisk. A przecież różnią się one od siebie tak bardzo, jak zapisany na nasionach akacji tekst mrówki od pozornie czytelnych wzorów, w które dla naszego oka układają się plechy porostów na przydrożnym głazie. Nie mam wątpliwości, że nazwę „porosty” (lichens) wybrała Le Guin w pełni świadomie, choć autorka polskiego tłumaczenia, niewiele myśląc, zastąpiła ją słowem „mchy" (mosses).W przeciwieństwie do tych ostatnich, porosty to zwykle organizmy złożone, symbionty grzybów i glonów, co lepiej uwydatnia ich inna nazwa: zlichenizowane grzyby. Już w czasie, kiedy powstało opowiadanie, należały one do dwóch odrębnych grup systematycznych, dziś zaś uważa się je wręcz za przedstawicieli dwóch odrębnych królestw. Łatwo więc sobie wyobrazić, jak bardzo język porostów jako symbiontów musiałby się różnić od środków ekspresji nieproblematycznych zgoła bakłażanów. Jak mi się wydaje, stawką mockumentarnego gestu, którym Le Guin ponad cztery dekady temu zestawiła trzy odmienne teksty z nieistniejącego czasopisma lingwistów, jest wyraźne pokazanie zarówno uzurpacji naszych zabiegów porządkujących,jak $\mathrm{i}$ ich wysokiej ceny. Za złudzenie panowania nad światem płacimy usunięciem w cień całej jego wielorakości i różnorodności, pominięciem tych pozornie nieistotnych różnic, które wszakże świadczą o istnieniu wielu światów.

To, co w opowiadaniu The Author of the Acacia Seeds ukrywa się w przemyślanym zestawieniu niejednorodnych fragmentów, przedmiotem pogłębionej

3 U.K. Le Guin The Author of the Acacia Seeds. 
analizy w szkicu Krążaca referencja uczynił Bruno Latour ${ }^{4}$. Wcześniej francuski socjolog i filozof nauki wykorzystywał narzędzia etnologów i antropologów, badając praktyki naukowców w laboratoriach jako miejscach produkcji niepodważalnej wiedzy o świecie ${ }^{5}$. Na początku lat 9o. postanowił jednak podjąć epistemologiczną kwestię referencji języka nauki w bezpośredniej konfrontacji z przyrodą. Uzbrojony w aparat fotograficzny wyruszył do dalekiej Brazylii jako obserwator kilkuosobowej wyprawy botaników, pedologów i geologów, której zadanie polegało na zbadaniu dynamiki roślinności na pograniczu amazońskiej puszczy i sawanny w rejonie Boa Vista. Jego „foto-filozoficzny montaż" ${ }^{\prime}$, jak sam go nazywa, szuka odpowiedzi na banalne z pozoru pytanie o relację między językiem a światem, dlatego zdaje się wyraźnym echem wcześniejszego o niemal dwie dekady tekstu Le Guin. Także ich odpowiedzi, choć sformułowane w innych językach, wiele się nie różnią. Zarówno Latour, jak Le Guin pokazują, że naukowcy niepodzielnie panują nad światem tylko w chwili, kiedy traktując go niczym bezwolną materię do dyspozycji i dowolnego użycia, zapewnią mu „formę dwuwymiarowych, dających się nałożyć na siebie i powiązać inskrypcji"7. Nigdzie zaś nie widać tego lepiej niż pośród bujnej roślinności amazońskiej puszczy. Uczestnicy wyprawy, której towarzyszy Latour, rozpoczynają bowiem zaplanowane badania od wyznaczenia w tym obcym dla nich terenie własnych punktów orientacyjnych - oznaczają numerami drzewa, rozciągają mocne nici siatki triangulacyjnej i tym podobne. Inaczej mówiąc, zmieniają fragment świata w laboratorium, gdzie nadal liczą się jedynie te jego elementy, które uznali za warte uwagi. Nic więc dziwnego, że Latour krótko i trafnie podsumowuje ich zabiegi: tylko gubiąc z oczu las, zyskujemy wiedzę o nim.

W opublikowanym po angielsku szkicu Krążaca referencja z typowym dla Francuza wyczuciem dla wieloznaczności słów zwrócił Latour uwagę na oddający ten paradoks straty i zysku rzeczownik „oversight”. Z nadzorczym spojrzeniem, którym obejmujemy wybrany fragment świata jednym rzutem oka,

4 B. Latour Krążąca referencja. Próbkowanie glebyw Puszczy Amazońskiej, przeł. K. Abriszewski, w: B. Latour Nadzieja Pandory. Eseje o rzeczywistości w studiach nad nauka [1999], red. K. Abriszewski, Wydawnictwo Naukowe UMK, Toruń 2013, s. 55-112.

5 Por. B. Latour, S. Woolgar Laboratory Life: The Construction of Scientific Facts [1979], 2nd ed., Princeton University Press, Princeton 1986; B. Latour Science in Action: How to Follow Scientists and Engineers through Society, Harvard University Press, Cambridge 1987.

6 B. Latour Krążq̨ca referencja..., s. 55.

7 Tamże, s. 60. 
nierozerwalnie wiąże się przecież niedopatrzenie czy przeoczenie. Przeoczenie drzew, które składają się na poznawany przez nas z władczego dystansu las. Co istotne, w Krążącej referencji Latour wnikliwie i krok po kroku śledzi ten proces. Myli bowiem wrażenie, jak uzasadnia, jakoby dyskurs naukowy odbijał w sobie świat niczym lustro, a typowe dlań specjalistyczne terminy wprost odsyłały do rzeczy i zjawisk. Nie bez przyczyny źródłowy dla pojęcia „referencja” łaciński czasownik „referre” znaczy „od-nosić, od-syłać”. Jeśli nawet dyskurs naukowy odbija w sobie świat, to jedynie dlatego, że ten ostatni oddaje mu obraz, który wcześniej od niego otrzymał, tym samym go potwierdzając. Dlatego wielu okrążeń tytułowej referencji trzeba, żeby od pobranych próbek gleby przejść choćby do wyrysowanego na papierze milimetrowym diagramu, przedstawiającego pionowy przekrój poprzeczny zbadanego terenu. Latour opisuje ten proces jako łańcuch kolejnych etapów substytucji czy transformacji, w których - wbrew naszym oczekiwaniom, żywiącym się konwencjami sztuki realistycznej - podobieństwo nie odgrywa najmniejszej roli. Liczy się natomiast coś zgoła innego. Podlegające substytucji elementy za każdym razem funkcjonują jako znak dla elementu poprzedniego, zaś jako konkretna rzecz dla następnego. Co nawet ważniejsze, ten łańcuch musi pozostać nieprzerwany i w pełni odwracalny. Latour więc podkreśla: „Następstwo etapów musi dawać się zrekonstruować, pozwalając na ruch w obie strony. Jeśli łańcuch zostanie przerwany w jakimkolwiek punkcie, przestaje przenosić prawdę - oznacza to, że przestaje ją wytwarzać, konstruować, tropić i kierować"s. Podobne krążenie referencji sprawiało, że lingwiści w opowiadaniu Le Guin mogli zasadnie oczekiwać tego, że już niedługo potrafią odcyfrować nie tylko język porostów, ale i samej ziemi.

Choć amerykańska antropolożka Anna Lowenhaupt Tsing nie nawiązuje wprost do tych ustaleń Latoura, kiedy w artykule On Nonscalability pisze o szkodliwej dominacji skali, to przecież odsłania podobny mechanizm u podstaw tradycyjnych paradygmatów naukowych, które wiele łączy z ideą kapitalistycznej ekspansji i wizją niepowstrzymanego postępu, tożsamą z nowoczesnością. Jak tłumaczy Tsing, najważniejszą cechą skali jest jej zdolność do tego, żeby „powiększać się - i powiększać, i powiększać - nie zmuszając do ponownego przemyślenia podstawowych założeń"9. Dzięki temu można

8 Tamże, s. 102-103.

9 A. Lowenhaupt Tsing On Scalability: The Living World Is Not Amenable to Precision-Nested Scale, "Common Knowledge" 2012 No. 3, s. 505. Zob. także: A. Lowenhaupt Tsing, The Mushroom at the End of the World. On the Possibility of Life in Capitalist Ruins, Princeton University Press, Princeton 2015 . 
łatwo zmienić skalę, przesuwając się po niej w górę i w dół niczym po definiowanym przez Latoura łańcuchu substytucji, bez potrzeby weryfikowania przyjętej na początku metodologii badań czy planu działań. Niczym krążąca referencja, skalowalność blokuje zdolność do zauważania różnorodności, pozwalając nie tylko na „podbój” natury czy, bardziej ogólnie, wytwarzanie światów. Ona także wtórnie naturalizuje te powstające światy, maskując biologiczną czy kulturową odmienność, zręcznie przy tym wykorzystując elementy nieskalowalne, nawet kiedy usuwa je na margines lub wymazuje. Tsing nie ma wątpliwości, że kiedy emergencja staje się ważniejsza niż ekspansja (kolonialna, ekonomiczna, technologiczna etc.), nadszedł dziś czas na poważne zmiany w sposobach gromadzenia i porządkowania wiedzy. Dotąd poszczególne nauki gromadziły jedynie takie dane, które bez problemu zgadzały się z przyjętymi u ich początku standardami, gwarantującymi skalowalność wiedzy i tym samym jej postępującą kumulację. Dlatego teoria nieskalowalności, proponowana jako alternatywa do hegemonii skalowalnych konceptualizacji świata, stawia sobie za zadanie krytyczną analizę wcześniejszych praktyk naukowych, która przede wszystkim odbierze im pozór naturalności, wydobywając na jaw ich historyczność. Jak bowiem twierdzi Tsing, rozwijające się w czasach podboju Nowego Świata nauki eksperymentalne mają u swoich podstaw ten sam model, co kapitalistyczna ekspansja: model tropikalnej plantacji trzciny cukrowej. W gościnnym wykładzie Feral Biologies na University College London w lutym 2015 roku zachęcała wobec tego, żeby niedawno wyodrębnioną przez geologów epokę w dziejach Ziemi, coraz powszechniej nazywaną antropocenem, określać trafniejszym terminem plantacjocen ${ }^{10}$. Dopiero wtedy wyraźny stanie się nadal chętnie pomijany w tym kontekście związek grożącej nam katastrofy ekologicznej z założeniami uprawianych nauk, nie tylko eksperymentalnych.

\section{Plantacje i uprawianie nauki}

Zanim Latour na przykładzie sond pedologicznych i klasyfikowania pozyskanych próbek gleby przejdzie do wyjaśniania zasad tytułowego krążenia referencji, na krótko zatrzymuje się przy kwestii zbierania okazów przez botaników, z ich taksonomiczną klasyfikacją, suszeniem, etykietowaniem i przechowywaniem. Chodzi tu oczywiście o klasyczny zabieg retoryczny, który

Por. D. Haraway Making Kin: Anthropocene, Capitalocene, Plantationocene, Chthulucene, „Environmental Humanities" 2015 No. 6, s. 159-165. 
pomaga przybliżyć czytelnikom to, co nieznane, za pośrednictwem tego, co znane im bardziej. Zapewne wielu z nich poznało - nawet w praktyce - ideę zielnika na lekcjach przyrody, wie zatem o podstawach botaniki więcej niż o gleboznawstwie. Mam jednak wrażenie, że na retoryce w Krażeniu referencji bynajmniej się nie kończy. O egzotycznych roślinach z Nowego Świata donosili w swoich relacjach uczestnicy pierwszych wypraw kolonialnych czy Jezuici, a następnie przywozili jako żywe czy zasuszone okazy na stary kontynent, często z nadzieją na ich właściwości lecznicze. Stanowiły one ponadto niezbity dowód na to, że proponowane w pismach Arystotelesa i Teofrasta, Diskurydesa i Piliniusza Starszego, nadal obowiązujące klasyfikacje nie są na tyle pojemne, by dało się włączyć w nie bez problemu nowe gatunki i grupy. A nie było ich mało. Choćby opublikowany w 1636 roku pierwszy katalog paryskiego ogrodu botanicznego Jardin du Roi zarejestrował ponad 1800 różnych roślin. Nic więc dziwnego, że w tej sytuacji coraz bardziej nieuchronna stawała się gruntowna weryfikacja europejskiego dziedzictwa. Co ważniejsze, botanika była także tą dziedziną nauk eksperymentalnych, w której stosunkowo szybko pojawiły się pokusy stworzenia nowych systematyzacji na podstawie istniejących już kolekcji okazów z różnych stron świata. Jak z lekką ironią tłumaczy Peter Dear, „nazwy dają się przecież łatwiej niż okazy uporządkować w uniwersalne i wszędzie obowiązujące systemy taksonomiczne"11. Tak więc u schyłku XVII wieku "gramatykę" botaniki zaproponowali najpierw John Ray w Anglii i Joseph Pitton de Tournefort we Francji, a niemal pół wieku później szwedzki przyrodnik i lekarz Karol Linneusz opublikował Systema Naturae i Genera Plantarum, które nadal stanowią podstawę taksonomii w botanice.

We wcześniejszej od przywołanego artykułu na temat (nie)skalowalności książce Friction Tsing poszła nawet o krok dalej niż Latour, gdyż dążący do unifikacji globalnej wiedzy botaniczny system taksonomiczny z jego ambicjami do uniwersalizacji uznała za rzeczywisty model pozostałych nauk ${ }^{12}$. Mógł on zaś powstać przede wszystkim dlatego, że europejscy uczeni skutecznie wyeliminowali lokalnych informatorów i pośrednictwo pozaeuropejskiej wiedzy. W efekcie to system jako jaki - nie zaś jego części składowe, konkretne rośliny - stał się podstawowym źródłem wiedzy i uwzględniał nowe okazy tylko w takim zakresie, w jakim potwierdzały jego podstawowe założenia.

11 P. Dear Revolutionizing the Sciences: European Knowledge and Its Ambition, 1500-1700, Palgrave, Basingstoke 2001, S. 129.

12 A. Lowenhaupt Tsing Friction. An Ethnography of Global Connection, Princeton University Press, Princeton-Oxford 2005. 
Na dowód Tsing przywołuje cytat wprost z pism Linneusza: „System jest dla botaniki nicią Ariadny, bez której rządziłby w niej jedynie chaos. Weźmy, na przykład, nieznaną roślinę z Indii, i niech jakiś botanik amator przeszukuje stosy opisów, rysunków i indeksów; na pewno nie znajdzie jej inaczej niż przez czysty przypadek. Za to systematyk oznaczy ją od razu, niezależnie od tego, czy będzie już znana czy nowa. [...] System wskazuje rośliny, nawet takie, których sam nie wymienia, a tego nie są w stanie zagwarantować wykazy w żadnym katalogu"'13. Nic też lepiej niż ten cytat nie pokazuje, że roślina nie mogła uchodzić za naukowy okaz, póki nie odebrano jej lokalnej nazwy i nie wyjęto jej z lokalnego systemu wiedzy, obejmując jednym imperialnym spojrzeniem.

Nawet jeśli słowo „plantacja” kojarzy się nam przede wszystkim z korzystającymi z niewolniczej pracy wielkimi uprawami bawełny na południu Stanów Zjednoczonych, nie tam metodą prób i błędów narodziło się to, co Philip D. Curtin już w tytule swojej pracy nazywa kompleksem plantacji ${ }^{14}$. Na myśli ma zaś uprawy rozmnażającej się wegetatywnie trzciny cukrowej z grupy, którą Linneusz nazwał Saccharum officinarum. Mówi zaś o całym kompleksie plantacji, ponieważ chce przedstawić nie tylko rozwój praktyk związanych z jej uprawami i wpływ tych upraw na porządek ekonomiczno-polityczny w świecie, pod ścisłą kontrolą europejskich mocarstw kolonialnych. Stara się również wpisać tę historię w szerszy o wiele system wymian między pięcioma kontynentami: wiele z towarów, które wymieniano za niewolników z Afryki, pochodziło przecież z Indii; kupowano je tam, płacąc srebrem z kopalń Ameryki Południowej, zaś Europa i Ameryka Północna dostarczały tam drewno i żywność, konsumując cukier, rum, kawę, bawełnę i wiele innych produktów. Dzięki tym rozbudowanym sieciom wymian, plantacje trzciny cukrowej mogły ograniczyć się wyłącznie do produkcji i sprzedaży cukru. Nie uprawiano na nich dosłownie nic więcej, nawet na własny użytek. Cała żywność dla właścicieli plantacji i niewolników pochodziła właściwie z Europy, podobnie jak sadzonki trzciny. Tak właśnie ukształtował się, krok po kroku, model wysoce wyspecjalizowanej, monokulturowej, modułowej i samowystarczalnej uprawy, która przynosi największe korzyści w chwili, kiedy kolejne plantacje, coraz większe i dysponujące coraz nowszymi technologiami, powstają na nowych terenach jako replika czy odwzorowanie starych. Ekonomiści

13 Tamże, s. 93-94.

14 Ph. D. Curtin The Rise and Fall of the Plantation Complex. Essays in Atlantic History, Cambridge University Press, Cambridge 1990. 
mówią w takim przypadku o korzyściach, które płyną z tego, że za każdym razem zaczyna się od czystej karty (clean-slate advantage). Żeby się o tym przekonać, dość rzucić okiem na ich przywołaną nawet w wielkim skrócie historię.

Jak przypomina Curtin, pierwsze plantacje trzciny cukrowej, pochodzącej zapewne z Nowej Gwinei i przywiezionej do Europy przez Arabów z Azji Południowo-Wschodniej, pojawiły się na wschodnich obrzeżach basenu Morza Śródziemnego i sięgają czasów wypraw krzyżowych. W XIII wieku centrum produkcji cukru stał się Cypr, gdzie m.in. inwestowali bogaci kupcy weneccy, a zatem od samego początku ten kompleks rozwijał się jako część gospodarki wczesnokapitalistycznej. Na początku XV wieku uprawa trzciny przeniosła się na atlantyckie wyspy w rejonie Zatoki Gwinejskiej, zaś Portugalczycy na Maderze, która ze względów klimatycznych nie do końca sprzyjała tego typu uprawie, zaczęli przeprowadzać pierwsze eksperymenty z systemami irygacyjnymi i terraformowaniem, usuwając całą miejscową roślinność i dostosowując ukształtowanie terenu do potrzeb monokulturowej uprawy. Nie tylko ułatwiało to kontrolę nad jednoczesnym dojrzewaniem i zbiorami, ale także umożliwiało replikowanie istniejących już praktyk na nowych obszarach. Historyczka sztuki jill Casid, badająca relacje między krajobrazem a gospodarką kolonialną, nadaje efektowi takich zabiegów wiele mówiącą nazwę: „hybrydyczny krajobraz agro-przemysłowy, krajobraz-maszyna”"15. Ścisła dyscyplina ludzi i nieludzi w znaczeniu, jakim nadał temu pojęciu Michel Foucault, pisząc o rozbudowanych o wiele bardziej systemach władzy-wiedzy, stanowiła podstawę powodzenia. Jednocześnie postęp technologiczny w obróbce ścinanych łodyg spowodował, że dzięki coraz większym i sprawniejszym młynom dało się obrabiać coraz większe pola, zatrudniając coraz więcej ludzi. Jednak eksperymenty na Maderze przyniosły dalekosiężne skutki dopiero w latach 40. XVI wieku, kiedy uprawa trzciny cukrowej dotarła do Brazylii, leżącej korzystnie na drodze portugalskich statków do Indii. Choć pozyskiwany tu cukier miał dłuższą drogę na europejskie rynki zbytu, to znacznie bliżej było stąd do tej części Afryki, z której pochodziła tania siła robocza. A na brazylijskich plantacjach, o czym często się zapomina, pracowało przecież po wielekroć więcej czarnych niewolników niż przy uprawie bawełny w Stanach Zjednoczonych. Tutaj też najpóźniej na zachodniej półkuli zniesiono niewolnictwo, bo dopiero w 1888 roku. Co istotne, na

15 J.H. Casid Sowing Empire: Landscape and Colonization, University of Minnesota Press, Minneapolis 2005 , S. 44 . 
tutejszych plantacjach po raz pierwszy na taką skalę wprowadzono metodę całodziennej pracy w polu i pod ścisłym nadzorem niewielkich grup niewolników, w których każdy miał dokładnie wyznaczone zadania i stanowił łatwy do zastąpienia $\mathrm{w}$ razie potrzeby element niemal mechanicznie działającej całości. Nie mogło zresztą być inaczej ze względu na zawinioną przez wysoką śmiertelność konieczność nieustannego odnawiania i szybkiego przystosowywania zasobów siły roboczej. To właśnie w Brazylii dotychczasowe praktyki, często udoskonalane odrębnie, utworzyły u progu XVII wieku całość. Wtedy też ten sprawnie już funkcjonujący kompleks został wprowadzony na francuskich i brytyjskich Karaibach i rozpoczęła się tzw. rewolucja cukrowa.

Rozmiary tej rewolucji najlepiej bodaj obrazuje przykład wyspy Barbados, która w 1637 roku nie produkowała jeszcze ani grama cukru. Jednak ledwie trzydzieści lat później tutejsza produkcja cukru zaspokajała $65 \%$ całego zapotrzebowania na Wyspach Brytyjskich. Aż 8o\% wyspy zarosła trzcina cukrowa, zajmując dosłownie każdy skrawek ziemi nadającej się do uprawy. Wielcy plantatorzy pod każdym względem - społecznym, ekonomicznym, politycznym - zdominowali miejscową społeczność. Już wkrótce liczba mieszkańców wzrosła też do tego stopnia, że czterokrotnie przewyższyła gęstość zaludnienia w Wielkiej Brytanii. Oczywiście znaczną większość z nich stanowili niewolnicy. Na początku XIX wieku korzyści płynące z zaczynania od czystej karty poznała jeszcze Kuba i Puerto Rico, zaś płodne ziemie i nowe technologie z Europy sprawiły, że około 1870 roku kubańskie plantacje zaspokajały niemal połowę zapotrzebowania całego rynku cukru. W tym miejscu należy jednak wspomnieć o czymś innym. Curtin udowadnia bowiem, że sprawdzony już model plantacji trzciny cukrowej, złożony ze stałych i regularnych modułów, został następnie z powodzeniem zaadaptowany w brazylijskich kopalniach złota w Minas Gerais. Na tym samym modelu wzorowali się także właściciele pierwszych fabryk w Europie. Dlatego też w przywołanym wcześniej artykule podkreśla Tsing, że skalowalność pracy ludzkiej leży u samych podstaw gospodarki kapitalistycznej i nierozerwalnie z nią związanej idei postępu. W miarę upowszechniania się tej idei skalowalne podejście zdominowało w XX wieku większość sfer naszego życia. Wtedy też choćby nowym rodzajem trzciny cukrowej stały się lasy, uprawiane monokulturowo na skalę przemysłową, maszynowo pielęgnowane, ścinane i obrabiane. Niedawna wycinka w Puszczy Białowieskiej i plany masowego zalesiania sprawiają, że przekonanie Tsing o tym, że „wiele projektów w obronie życia - zarówno ludzi, jak nieludzi - realizowanych jest na ruinach skalowalnych 
przedsięwzięć"16 , nabrało dla nas aktualnej wymowy. Choć wskazuje ona wyraźnie na potrzebę ujawnienia praktyk naturalizujących skalowalność przez pokazanie ich historyczności, pomija właściwie pytanie o to, jakimi drogami przeniknęły one na teren nowych nauk eksperymentalnych w połowie XVII wieku. A jak tymczasem podejrzewam, niebagatelną rolę w ich karierze odegrała inna egzotyczna roślina i napój sporządzany z jej ziaren, czyli kawa, i kawiarnie.

Inaczej niż w przypadku trzciny cukrowej plantacje kawy powstały stosunkowo późno, pierwszą założyli w 1696 roku Holendrzy na Jawie, a potem na Karaibach. Tajemnicy ich uprawy strzegli bowiem zazdrośnie arabscy kupcy z Jemenu. Rycina przedstawiająca krzew kawowca z charakterystycznymi czerwonymi jagodami pojawiła się dopiero w wydanym w 1640 roku Theatrum Botanicum Johna Parkinsona, zaś członkowie Royal Society daremnie starali się zdobyć nie tylko żywy okaz, lecz choćby nasiona. Oczywiście wieści o tej roślinie i napoju z jego ziaren docierały na Wyspy Brytyjskie za pośrednictwem relacji z podróży i raportów o egzotycznych krajach, głównie Półwyspu Arabskiego. Nic więc dziwnego, że Samuel Hartlib o jednej z pierwszych kawiarni w Londynie pisał „Turkish alehouse”, stawiając znak równości między orientalnym napojem a miejscowym mocnym, ciemnym piwem. Jednak przez kilka dobrych lat zimujące w drodze do Indii w jemeńskim porcie Mokka brytyjskie statki dostarczały kawę wyłącznie na rynki azjatyckie. Jak w The Social Life of Coffee pisze Brian Cowan ${ }^{17}$, pierwsze ziarna kawy dotarły do Londynu w 1628 roku. Ich hurtowa sprzedaż rozpoczęła się jednak dobre trzydzieści lat później. Co ciekawe, Brytyjczycy traktowali je początkowo jak zresztą większość egzotycznych roślin i przypraw - jak środek medyczny, pomocny w załamaniach nerwowych. Thomas Willis, znakomity lekarz, jeden z założycieli Royal Society i twórca neurologii, nie raz otwarcie deklarował, że woli wysłać cierpiących na tę przypadłość pacjentów do kawiarni niż do apteki. Pierwszą kawiarnię pod wdzięczną nazwą The Angel otworzył w 1650 roku w Oksfordzie Żyd o imieniu Jacob. Już wtedy łączyła ona sferę publiczną z prywatną, co najlepiej oddaje angielskie określenie „public house” (zresztą część kawiarni nie była w rzeczywistości niczym więcej niż największym pomieszczeniem w domu właściciela). Dlatego Jürgen Habermas podkreślał

16 A. Lowenhaupt Tsing On Nonscalability: The Living World Is Not Amenable to Precision-Nested Scale, "Common Knowledge" 2012 No 3, s. 515.

17 B. Cowan The Social Life of Coffee. The Emergence of the British Coffeehouse, Yale University Press, New Haven-London 2005. 
ich istotny udział w kształtowaniu się nowoczesnego społeczeństwa obywatelskiego ${ }^{18}$. Dwa lata później podobne instytucje zaczęły niczym grzyby po deszczu wyrastać w Londynie. Kiedy więc na początku XVIII wieku moda na kawę dotarła na kontynent i Amsterdam mógł się pochwalić 32 kawiarniami, Londyn liczył ich co najmniej kilka setek. W każdym razie ich oficjalny rejestr z 1734 roku podaje liczbę 551, nie obejmuje jednak tych kawiarni, które nie posiadały licencji. W tym samym mniej więcej czasie Brytyjczycy zaczęli tracić wcześniejsze zainteresowanie dla kawy, po części ze względu na politykę celną i wzrost cen. Już wkrótce zastąpiły ją herbata i dżin.

Co istotne, nie bez przyczyny pierwsza kawiarnia powstała w Oksfordzie i często gościła przyszłych założycieli Royal Society, młodego Christophera Wrena czy Roberta Hooke'a. Do najbardziej gorliwych propagatorów kawy i kawiarni należeli od samego początku brytyjscy virtuosi, podzielający tę samą wrażliwość, zwyczaje i intelektualne preferencje, określane mianem "curiosity" (ciekawość). Obejmowała zaś ona wiele rzeczy: od dzieł sztuki przez egzotyczne rośliny i zwierzęta po urządzenia mechaniczne. To przede wszystkim za ich sprawą najpierw oksfordzkie, a potem londyńskie kawiarnie zaczęto nazywać „groszowymi uniwersytetami”. W przeciwieństwie do oficjalnych instytucji, nadal propagujących dalece teoretyczną wiedzę, upowszechniały one wśród pijących kawę gości, wywodzących się z najrozmaitszych sfer społecznych, nowy typ wiedzy: opartej na codziennych doświadczeniach i mającej praktyczne zastosowanie. Nawet jeśli brakuje dowodów na to, że w zaprzyjaźnionych z członkami Royal Society kawiarniach rzeczywiście przeprowadzano eksperymenty, to z całą pewnością dawały one istotną szansę poszerzenia zamkniętych dla wielu laboratoriów o przestrzeń publiczną, w której o tych eksperymentach można było informować i toczyć na ich temat gorące dyskusje, a także pokazywać najnowsze naukowe instrumenty, jak często robił to Hooke. Korzystał przy tym chętnie z doświadczeń innych bywalców, gromadząc wiedzę praktyczną w rozmowach ze służącymi, rzemieślnikami i marynarzami. Część kawiarni posiadała też zbiory książek, udostępniała lub prowadziła sprzedaż traktatów i pamfletów, zarówno rękopiśmiennych, jak i drukowanych, prenumerowała miejscową i zagraniczną prasę, a nawet wydawała własne gazety, zatrudniając najlepsze pióra. Oddając im sprawiedliwość, Cowan zatem pisze: „Naukowe laboratorium, akademickie czasopismo, wykształcone społeczeństwo i kawiarnie to wszystko owoce

18 Por. J. Habermas Strukturalne przeobrażenia sfery publicznej [1962], przeł. M. Łukasiewicz, W. Lipnik, PWN, Warszawa 2008. 
społecznego i kulturowego dziedzictwa wirtuozów"19. Wśród owoców tego dziedzictwa, jak można zasadnie podejrzewać, znajduje się także wykorzystanie skalowalności w laboratoriach i w ściśle sformalizowanych raportach o przeprowadzanych w nich doświadczeniach oraz upowszechnienie jej modelu w ramach działalności "groszowych uniwersytetów". Nie tylko więc trzcina cukrowa, lecz także krzew kawowca odegrał ważną rolę w narodzinach nowych paradygmatów naukowych i przygotowywaniu świata do zwycięstwa skalowalności, utożsamianej z nowoczesnością i postępem. Jednak trzy i pół wieku później to właśnie rośliny, choćby w ramach powstających dopiero studiów wielogatunkowych (multispecies studies), stają się cennymi - i coraz bardziej docenianymi - przewodnikami po różnorodności praktyk życiowych, wytwarzających odrębne światy ${ }^{20}$.

\section{Na peryferiach antropologii}

Na jednej z pierwszych stron wspomnianego już szkicu Krążaca referencja Latour nie omieszkał zaznaczyć w nawiasie: „Z góry przepraszam czytelnika za to, że pominę wiele aspektów tej wyprawy badawczej, które wiążą się z kolonializmem"21. Dzięki temu chciał poświęcić uwagę jedynie filozoficznemu zagadnieniu referencji. Po niemal dwóch dekadach od czasu, kiedy w Nadziei Pandory ukazała się ostateczna wersja tego szkicu, widać jednak wyraźnie, że to właśnie uwzględnienie tych aspektów, które wiążą się z kolonializmem, pozwala w nowy sposób spojrzeć na wiele tradycyjnych zagadnień filozoficznych. Wielu badaczy z kręgu studiów dekolonialnych, naśladując podstawowy gest Prowincjonalizacji Europy Dipesha Chakrabarty'ego ${ }^{22}$, podejmuje - nierzadko bardzo udane - wysiłki w celu prowincjonalizacji tych zagadnień, upowszechniając nieskalowalne praktyki gromadzenia i porządkowania wiedzy, na długi czas wymazane z naszego pola widzenia przez zachodnią episteme.

19 Tamże, s. 260.

20 Por. choćby Th. van Dooren, E. Kirksey, U. Münser Multispecies Studies: Cultivating Arts of Attentiveness, "Environmental Humanities” 2016 No. 1, special issue: Multispecies Studies, s. 1-23; M. Marder Plant-Thinking. A Philosophy of Vegetal Life, Columbia University Press, New York 2013.

B. Latour Krążąca referencja..., s. 58.

Por. D. Chakrabarty Prowincjonalizacja Europy. Myśl postkolonialna i różnica historyczna [2000], przeł. D. Kołodziejczyk, T. Dobrogoszcz, E. Domańska, Wydawnictwo Poznańskie, Poznań 2011. 
W tym miejscu przywołam jedynie jedną z takich propozycji, gdyż narodziła się mniej więcej w tym samym czasie, kiedy powstawał szkic Latoura, w efekcie etnograficznych badań w tropikalnych lasach Amazonii, które w nieco innym rejonie prowadził kanadyjski antropolog Eduardo Kohn. Podczas gdy Latour podkreślał binarną opozycję między światem niemal pierwotnej natury a porządkującymi go zabiegami naukowców, nakładających na nieujarzmioną przyrodę własną siatkę oznaczników, Kohn postępuje zdecydowanie inaczej ${ }^{23}$.W pracy How Forests Think podkreśla od razu, że ekwadorska Amazonia, gdzie na badaniach terenowych spędził cztery lata i potem wielokrotnie powracał, to jedno z pierwszych miejsc indoktrynacji katolickiej i hiszpańskiej kolonizacji. Świat Indian Runa stanowi zatem jedyny w swoim rodzaju efekt długotrwałego mieszania się na różnych poziomach rdzennych wierzeń i kolonialnych wpływów. Przedmiot badań Kohna znajduje się tym samym na antypodach tego, który analizował Latour. Dzieje się tak nie tylko dlatego, że Indianie Runa po swojemu i od dawna zagospodarowali „dziewicze" dla europejskiego oka tereny, czyli od dawna stanowią one krajobraz społeczno-naturalny. Jak najlepiej pokazuje przykład boomu kauczukowego z końca XIX wieku, znane Runa elementy tego krajobrazu - lokalne łańcuchy troficzne, przestrzenne konfiguracje roślin i zwierząt oraz sieci hydrograficzne - znakomicie potrafili wykorzystać kolonizatorzy w pogoni za zyskiem. Przyjęcie miejscowej perspektywy nie pozwala więc mówić o binarnych opozycjach, jak robi to Latour. To wiele splątanych, nakładających się na siebie praktyk życiowych i ucieleśnionych punktów widzenia, w których ludzkiemu spojrzeniu nie przysługują żadne przywileje. Toteż nic w tym dziwnego, że właśnie tutaj przekonał się Kohn, że znaczenie może mieć sposób, w jaki patrzy na nas jaguar, a umiejętność przechwytywania perspektyw innych organizmów stała się podstawą jego antropologii pozaludzkiej, , ,antropologii, która w swoim podejściu do świata wprawdzie uznaje, lecz także daleko wychodzi poza ograniczenia specyficznych dla ludzi sposobów poznawania”24.

Jednym z podstawowych zadań tej nowej antropologii jest prowincjonalizacja języka i typowych dla niego schematów kognitywnych, z procesami symbolizacji na czele. Dopiero wtedy uda się nam zobaczyć, jak „semioza (tworzenie i interpretacja znaków) przenika cały żyjący świat i jednocześnie go ustanawia. To za sprawą podzielanych częściowo zdolności do semiozy

23 E. Kohn How Forests Think. Toward an Anthropology Beyond the Human, University of California Press, Berkeley-Los Angeles 2013. 
wielogatunkowe relacje nie tylko okazują się możliwe, lecz także analitycznie zrozumiałe"25. Czerpiąc inspiracje z pomijanych dotąd pism Charlesa Peirce'a na temat niesymbolicznych modalności reprezentacji w pozaludzkim świecie, na konkretnych przykładach przedstawia Kohn ikoniczne i indeksalne systemy znaczeń, które w postaci zwyczajów, regularności, wzorów, relacji, przyszłych możliwości i celów powstają i ujawniają się w światach poza ludzką kontrolą. Na takiej właśnie zasadzie tytułowe lasy mogą w jego podejściu myśleć. Dają bowiem schronienie wielu takim emergentnym miejscom narodzin znaczeń, które uznaje on za swoiste „ja” (selves) - źródło i zarazem wytwór procesów interpretacyjnych. Tak rozumiane bycie sobą (selfhood) nie ogranicza się przy tym do zwierząt, jak wspomniany jaguar. Żyją, a więc myślą i uczą się z własnych doświadczeń także rośliny, a może również formy nieorganiczne. Jak podkreśla Kohn, tropikalne lasy jedynie wzmacniają, a tym samym uwydatniają zasady, na jakich wszystko, co żyje, widzi, przedstawia sobie i poznaje, a także myśli. Nawet jeśli najczęściej czyni to w sposób wysoce ucieleśniony i niesymboliczny, daleki od tego, co nauczyliśmy się dostrzegać jako przyrodzone jedynie ludziom procesy myślowe i reprezentacje.

Trudno powiedzieć, co mogła mieć na myśli Le Guin, kiedy w usta prezydenta Therolinguistics Association wkładała słowa o stojącym nadal przed nami wyzwaniu roślin. Jednak ze sposobu, w jaki przeprowadziła krytykę języka jako narzędzia karygodnego ujednolicania przedmiotów naszego poznania, można domyślać się, że niczym Kohn szukała innych metod ponownego ożywienia świata, jakby powiedział Latour jako autor najnowszych prac o antropocenie i koniecznym przywróceniu sprawczości temu, co nas otacza $^{26}$. Jedno się bowiem z pewnością zmieniło od czasu, kiedy Le Guin pisała The Author of the Acacia Seeds. To, co wtedy zdawało się przerażającym zgoła wyzwaniem roślin, dziś stało się szansą konieczną do wykorzystania. Nie inaczej widzi to także Kohn. Również dla niego rośliny to bardziej szansa niż wyzwanie. Dlatego kończy swoją książkę w trybie warunkowym: jeśli chcemy przeżyć antropocen, musimy nauczyć się myśleć wraz z lasami i jak lasy, ta „wyłaniająca się i rozprzestrzeniająca się, wielowarstwowa i kakofoniczna sieć wzajemnie ustanawiających się, żywych i rosnących myśli"27.

25 Tamże, s. 9.

26 Por. np. B. Latour Agency at the Time of the Anthropocene, "New Literary History" 2014 No. 1, s. 1-18. 


\section{Abstract}

\section{Małgorzata Sugiera}

JAGIELLONIAN UNIVERSITY (CRACOW)

Ecologies of Plants and Knowledge

Taking Ursula Le Guin's early short story 'The Author of the Acacia Seeds and Other Extracts from the Journal of the Association of Therolinguistics' as a point of departure, Sugiera explores Bruno Latour's concept of circulating reference and Anna Lowenhaupt Tsing's notion of scalability as two complementary critical perspectives on the paradigm of accumulating and ordering knowledge. This paradigm, which emerged with the scientific revolution and applies to this day, is based on a model that is fundamental for modernity, namely that of the sugar plantation in the New World. Its transposition into the experimental sciences in the second half of the seventeenth century is closely related to the appearance of new public institutions in the British Isles, namely the coffeehouses that acted as 'penny universities'. Sugiera concludes by proposing new scientific practices inspired by trends in decolonialism, especially Eduard Kohn's beyondthe-human anthropology.

\section{Keywords}

Eduard Kohn, beyond-the-human anthropology, Ursula Le Guin, Bruno Latour, circulating reference, Anna Lowenhaupt Tsing, scalability, scientific revolution, knowledge production, sugar plantation, coffeehouse culture 